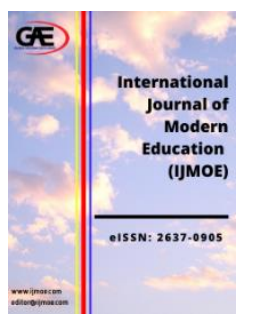

\author{
International Journal of Modern Education \\ (IJMOE) \\ Journal Website: http://ijmoe.com/ \\ eISSN: 2637-0905
}

\title{
FORMAL SCHOOLING AND THE PROCESS OF IDENTITY CONSTRUCTION: EXPERIENCES OF MALAYSIAN YOUTHS IN 'BAD' SCHOOLS
}

\author{
Dianna Suzieanna Mohamad Shah ${ }^{1 *}$, Airil Haimi Mohd Adnan ${ }^{2}$ \\ 1 Academy of Language Studies, Universiti Teknologi MARA Perak Branch, Seri Iskandar Campus, Malaysia \\ Email: dianna@uitm.edu.my \\ 2 Academy of Language Studies, Universiti Teknologi MARA Perak Branch, Seri Iskandar Campus, Malaysia \\ Email: admin@uforia.edu.my \\ * Corresponding Author
}

\section{Article Info:}

Article history:

Received date: 15.02 .2020

Revised date: 10.03.2020

Accepted date: 14.03.2020

Published date: 15.03.2020

\section{To cite this document:}

Shah, D. S. M., \& Adnan, A. H. M. (2020). Formal Schooling and the Process of Identity Construction: Experiences of Malaysian Youths in 'Bad' Schools. International Journal of Modern Education, 2(4), 78-89.

DOI: $10.35631 /$ IJMOE.24007.

\begin{abstract}
:
In human lifespan development, identity construction is central within social and personal experiences, even more so for teenagers and young adults (youths) who are looking for their sense of self and own identity. The construction of identity involves the growth of a whole person and the development of a stable sense of self. At the same time, the process of identity construction causes some youths to become self-conscious about how others perceive them; this usually results in repeated self-discovery and identity experiment cycles. Their identities are thus constructed and reconstructed as they try out different role types in different settings, such as in schools. The focus of this research paper is to examine the experience of formal schooling and how it relates to the identity process of Malaysian youths. Employing qualitative face-to-face interviews, data were collected from six research participants from a private university in Selangor, Malaysia who were purposively selected for this empirical research. Three criteria for participant selection were used: That they have been in rural schools for most of their lives, the schools adopt a very didactic focus, and the schools have a limited number of highly trained and motivated teachers; in other words, they have experienced being in 'bad' schools. The research participants were selected from two different academic programs: Three undergraduate students from Bachelor in Teaching English as a Second Language (TESL) and another three from the Bachelor in Law program. Two research questions were posed. First, where does the experience of formal schooling figure in the identity construction of these youths? And second, what roles do the formal experience of schooling play in the lifespan identity development of these youths? Although not generalisable to all youths in Malaysia, the experiences of the participants contribute to advancing our knowledge of identity construction through the process of formal schooling.
\end{abstract}




\section{Introduction}

Malaysia is trying to advance its system of formal education with the ultimate goal of becoming a global education destination by 2025. At the same time, the process of education in Malaysia continues its struggle to remain pertinent, to stimulate interests and to open up future occupational opportunities for local tertiary level students. That being said, there are now more specific criteria that employers need to look for in searching for prospective employees from the growing pool of tertiary level talents, especially in the post Industry 4.0 era in year 2020 and beyond (see Adnan, 2018; Rahmat, Adnan \& Mohtar, 2019). These criteria include communication skills, problem solving skills and also working with others (see World Economic Forum, 2016a, 2016b, 2018).

It is expected that future Malaysian graduates will have developed their identity potentials through school programs and from their 'lived experiences' within the formal schooling system. This is due to the fact that the formal school system offers structured training and encourages the mental, psychological and social development of all learners (Adnan \& Smith, 2001). In addition to the usual teaching and learning activities, a child or teenager can also learn other essential life skills such as teamwork, positive behaviour, cooperation, sharing and accountability (Adnan, 2006; Sylva, 1994). Schools are essentially the second home of children and teenagers in the postmodern era, as parents leave the home environment to earn a living (see Adnan, 2017a, 2017b). It is no surprise that the experience of schooling can somehow trigger changes in the personality development together with the personal and social identities of children and teenagers. Personality can be defined as the set of qualities that differentiate a person from other persons (see Soto \& Tackett, 2016), whilst identity is the subjective feeling of a person (i.e., personal identity) relating to her or his distinctive characteristics compared to others (i.e., social identity) (see Raburu, 2015; Stets \& Burke, 2014b). Identity construction is consequently critical in a person's life especially for children and teenagers. Through identity construction, individuals can understand themselves, build their self-esteem (Stets \& Burke, 2014a) and develop aspirations for the future, as well as to expand their 'life boundaries' based on experiences in the past and present (Smith, Walker, Fields, Brookins \& Seay, 1999).

\section{Literature Review}

This section looks closely at research literature related to the focus of this empirical effort. The section is separated into three subsections for clarity. First, the experience of schooling in the identities of children and teenagers. Second, the general effects of schooling on Malaysian youths and the global experience. Finally, this section closes with the problem statement and the research questions that guide this empirical research project.

\section{The Experience of Schooling in the Identities of Children and Teenagers}

In modern societies, formal schooling is one of the most critical stages of socialization that a child goes through outside of the home. Hence, it plays a fundamental role in human lifespan development especially as catalyst and conduit for the process of identity construction. It is for these reasons that many schools around the globe have prepared educational activities to create a holistic experience that aims to provide young people with a range of experiences that will both stretch the imagination and challenge their students. In addition, Sirin (2005) states that 
the facilities in school also play an important role in human development. However, to shape one's identity is not clear cut, due to the fact that identity is a complex and multifaceted phenomenon (see Abbasi, 2016; Adnan, 2013a, 2013b; Berezin, 2010; Burke \& Stets, 2009).

Agbenyega (2008) proposes a conceptual framework that looks at the interconnections between the school as a physical place, the school as a purveyor of teaching pedagogy, the school as a catalyst for identity construction and the school as a process of formal learning. These four constructs are illustrated in Figure 1. Within this framework, the school as a physical place contains both animate and inanimate goods and services that interact symbiotically to create a meaningful and fun environment. Agbenyega further explains that the 'goods' in schools may include teachers; classroom 'tools' like books, playground equipment, learning technologies as well as the general architectural setting of the classroom; and lastly, 'services' that may include cleaning and grounds staff, and also administration staff especially the head or the principal.
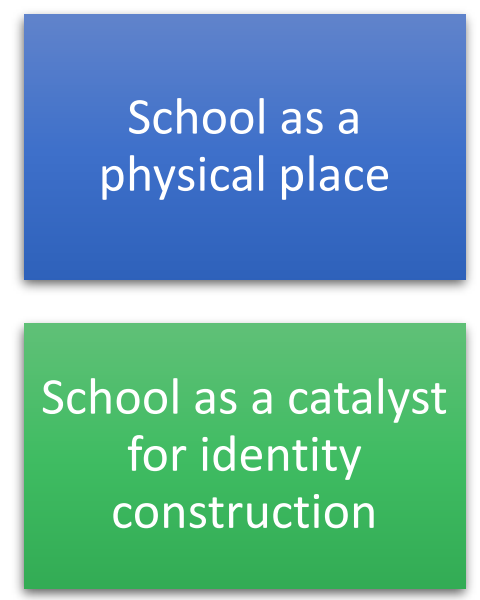

School as a

purveyor of

teaching pedagogy

School as a process

of formal learning

Figure 1: Conceptual Framework Examining the Interconnections Within Schools Source: Agbenyega (2008)

The key factor that distinguishes one school to the next is the distinction between its goods and services. This means that the classroom as a place has a purpose that is guided by the goods and services within it. A 'good' school is a place with ample and sufficient facilities such as teachers, technological tools and teaching materials that will enhance students' curiosity and ignite their passion for learning. As a result, the experience of schooling will affect health, behaviour, engagement, learning and performance; and ultimately, the overall lifespan development of students (see Zepatou, Loizidou, Chaloulakou \& Spyrellis, 2016).

\section{The General Effects of Schooling on Malaysian Youths and the Global Experience}

There are several aspects of formal schooling in Malaysia that need to be understood before we can scrutinise the position of these schools in the process of identity construction for Malaysian youths. First and foremost, the urban and rural divide in Malaysia impacts strongly on the experience of schooling and on the identities of Malaysian youths. In Malaysia, there are still schools situated in remote and hard-to-reach areas where the only transportation system is via rivers and/or harsh logging roads (see Marwan, Sumintono \& Mislan, 2012). As a result, some problems have arisen; examples include lack of school equipment and teacher shortage. The second aspect of formal schooling in Malaysian is teaching pedagogy. Some local teachers in Malaysian schools are still using the didactic method to teach. The didactic method can be defined as a teacher-centred classroom setting where students are merely passive listeners. This style of teaching does not encourage student interactions; rather, it focuses merely on presenting the subject matter as dry factual contents (Mahajan \& Kaushal, 2017). This situation Copyright (C) GLOBAL ACADEMIC EXCELLENCE (M) SDN BHD - All rights reserved 
negatively affects the process of revitalizing the school system in Malaysia as a whole. The third and last aspect is the patchy availability of very dedicated and highly trained teachers. This is detrimental to students and the entire system of Malaysian education, notwithstanding the mess created within rural communities that desperately need access to quality educational provisions (see Shah, Adnan, Perumal, Yusof, Veeravagu \& Kamarudin, 2020); the same problems are also faced by the rural Orang Asli or native communities across Peninsular Malaysia (see Adnan, 2012; Shah, Adnan, Mohd Salim, Yusof \& Tahir, 2020).

Looking at the issue of schooling from global lenses, in a study by Esteban-Guitart, MonrealBosch, Perera and Bastiani (2017) in Mexico, their participants were grouped into: Young indigenous students from remote areas with quite limited access to formal learning; young indigenous students from suburban areas; and young indigenous students from city areas (urban). These research participants were asked to define themselves through rough drawings.

The results showed that urban students can insert more elements of individualism into their drawings and their drawings are more descriptive of one's self. This suggests that the goods in a school setting will affect pedagogical behaviour, and the teaching and learning activities in the classroom. A good school with suitable and enough facilities will boost its students' trust and enhance their learning and performance. In the process, students in these schools will be able to adopt positive identity positions compared to students from a 'bad' school. A good school will also have enough highly trained and very motivated teachers who are able to use effective pedagogy to help students build their self-esteem and not just their store of knowledge. These teachers might opt, for instance, to use educational technologies or the Socratic method of teaching to help students become more independent. Learners are in charge of their own learning processes and will be able to acquire thinking skills leading to positive outcomes both educationally and emotionally (Delić \& Bećirović, 2016). These will all lead to more positive identity positions compared to students who are forced to learn in bad schools.

Agbenyega's (2008) framework is also parallel to S. Freire, Carvalho, A. Freire, Azeved and Oliveira's work (2009). The group states that the school is a social space occupied by various social agents who are empowered to guide students' behaviour and their interpretations, and these social agents can influence how an individual sees herself or himself and other people. Indeed, to help children and teenagers to construct positive identity roles, good schools will trump bad ones. But, in many cases, some youths of a nation will be unable to choose the 'best' schools for themselves due to their ethnicity, social stratification and low socioeconomic status of their families (Ilias \& Adnan, 2012).

\section{Problem Statement and Research Questions}

The research literature above brings us to the problem statement of this empirical project. In all modern societies in all countries of the world, the process of formal schooling has become prevalent and taken for granted in its implementation. In ideal situations, a school will be located in a good physical location, the teachers in that school will use a blend of challenging and engaging teaching techniques including the adoption of modern teaching and learning technologies, and there will be many highly trained and very motivated teachers in that school. In ideal situations also, a school will have many tools such as good books in a library, enough playground equipment, and also electronic gadgets and technologies in the classroom. These will be supplemented with good services, including hardworking cleaning and maintenance or grounds staff and highly experienced administration staff led by an outstanding school head or school principal. 
On the contrary, an ideal school is just not realistic enough for some youths who have to contend with learning in a bad school, leading to bad experiences and limited opportunities for growth and development. Owing to these reasons, an empirical research project was carried out guided by two research questions. First, where does the experience of formal schooling figure in the identity construction of these youths? Second, what roles do the formal experience of schooling play in the lifespan identity development of these youths? The following section details the research methods including the criteria for participant selection, the data collection method employed to gather 'thick' qualitative data, and the analysis that was carried out from the rich textual data record that was built during the research process.

\section{Research Methods}

This empirical research relies on six unique 'cases' to build its arguments. Case study method in qualitative research is a common method within the social sciences (see Adnan, 2013a, 2013b) because it allows for a comprehensive and 'rich' inquiry into one individual's experience, a group of people or an important social occurrence. To build detailed cases, one of the most important initial steps is criteria for participant selection. Three central criteria for participant selection were adopted in this research project: (1) The participant has been in rural schools for most of her or his life either at primary or secondary level, or both; (2) The participant describes his or her school as quite traditional where the teachers adopt a didactic focus and do not usually rely on more progressive teaching methods and novel educational technologies for teaching and learning; (3) The participant's school has a limited number of highly trained and very motivated teachers or even understaffed, either for teaching staff and administrative or support staff, or both. For lack of better terms, the participants were chosen due to the fact that they have experienced being pupils or students in bad schools but still managed to enter a university.

\section{Research Site and Research Participants}

At the end of the participants selection process, it was decided that participants will be chosen from a single research site so as to help with logistical issues. The site chosen is a famous and large private university in the city of Shah Alam, state of Selangor, Malaysia. The university chosen was established in 2002 when it started its first admission of students. Over those years, a lot of developments have transformed this university into its present form; the full university status that was granted in 2007 is likely to be the most significant. Their niche areas are now in the fields of medicine and health sciences, business and management, and other modern academic disciplines.

Six university undergraduates from the research site who fit the criteria for participant selection were purposively selected from two different academic programs: Three undergraduate students from the Bachelor in Teaching English as a Second Language (TESL) program and another three students from the Bachelor in Law program. Further, the selection of participants was influenced by other practical factors. The first is that these two programs are under the same school, which is the School of Education and Social Sciences. Next, three of the participants were Malay, one Chinese, one Sindhi and another, an Orang Asli ethnic from the Semai subethnic group. Only the Orang Asli participant was male whilst the others female. The participants were also from an age group we considered mature enough to provide useable and significant answers in interview sessions to enhance the quality of the data collected; all of them were between the ages of 22 to 26 years during our fieldwork in 2019. 


\section{Research Ethics and Sampling Technique}

With reference to research ethics to maintain the quality of this research project (Flick, 2002; Flick, von Kardoff \& Steinke, 2004), official permission was sought from the highest authority of the school (faculty) to engage degree students in that particular age range. In this empirical effort, purposive sampling was selected. This sampling technique depends on researchers for actual participant selection (e.g., individuals, cases, events, bodies). Typically, the sample will be small in comparison to probability sampling (see Showkat \& Parveen, 2017). The primary objective of purposive sampling is to hone on specific features of a group of people that will subsequently allow researchers to find answers to their central guiding questions (Etikan, Musa \& Alkassim, 2016). It should also be clear from this paragraph that the sampling technique employed is strongly aligned to case study research method.

\section{Qualitative Data Collection and Data Analysis}

Finally, the qualitative instrument chosen to amass empirical data was face-to-face interviews. Qualitative research methods, interviews for instance, will allow access to in-depth or 'thick' understanding of social phenomena (see Adnan, 2012, 2017a, 2017b; Alirezaei \& Roudsari, 2020; Kaplan, Kuhnt \& Steinert, 2020). Interviews are consequently very suitable where not much is understood about the social phenomena under study or where thorough understanding are needed from research participants (Burnard, Gill, Stewart, Treasure \& Chadwick, 2008). As for Gibson, Drennan, Hanna and Freeman (2000), the research interview is also very suitable for us to examine delicate issues, where individuals might shy away from talking about such issues within more open focus group discussion sessions.

Once the data were collected, textual data records were compiled (Major \& Savin-Baden, 2010) for each of the six participants. As norm in qualitative research projects, the data were then analysed based on themes and subthemes starting with the laborious process of data coding (Demain, Goncalves, Areia, Oliveira, Marcos, Marques, Parmar \& Hunt, 2015). At the end of the data collection process, on average, each of the participant was interviewed for nearly two hours. After those interviews were transcribed in full, the transcripts were shared with the participants to ensure that they agree with the data and for 'member checking' (Flick, von Kardoff \& Steinke, 2004). After coding and thematising, the results were then shared once more with each of the participant to close the member checking loop and to raise the 'quality' criteria (Flick, 2002; Stuckey, 2014) of this fully qualitative research project. Salient themes arising from the six cases are presented in the following section.

\section{Data Presentation}

This empirical research sought to explore the influence(s) of schooling on students' identity construction. The findings indicate that 'school place' characteristics such as types of teaching methods and roles of teachers impacted identity. This supports data from previous research (see S. Freire, Carvalho, A. Freire, Azevedo \& Oliveira, 2009). Three salient themes from this study are illustrated in Figure 2 and they are discussed, in turn, in the subsections below. 

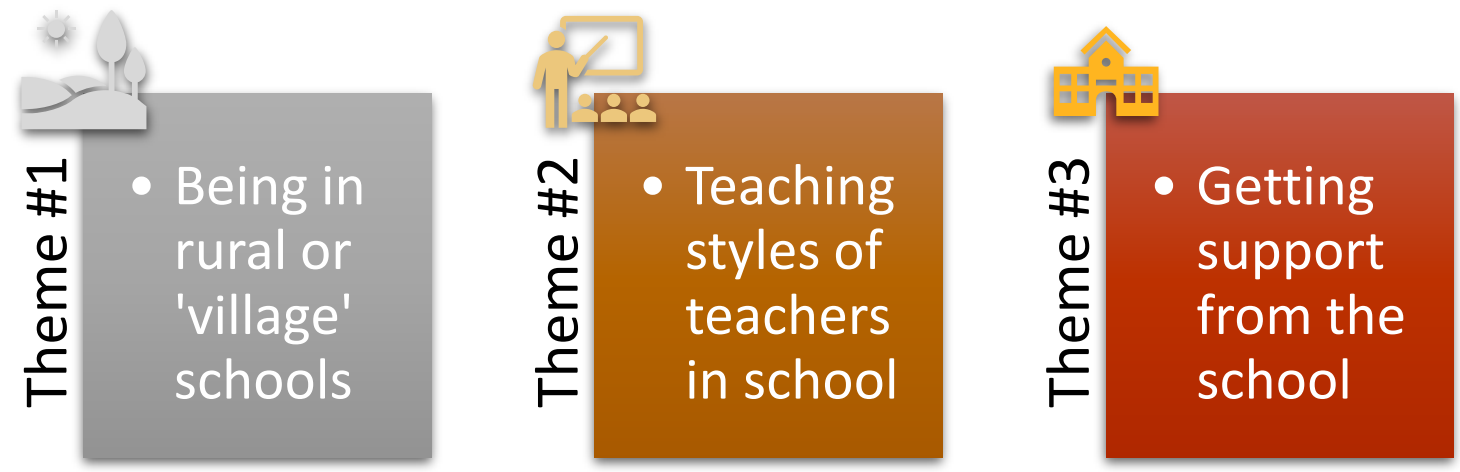

Figure 2: Experiences of Malaysian Youths in 'Bad' Schools

\section{Theme \#1 - Being in Rural or 'Village' Schools}

Due to the criteria we employed in the process of participant selection, all of the participants received their education in rural or village settings, for most of their lives, at primary and/or secondary school levels. There are two dimensions of the experience of being in these primary and/or secondary schools with reference to how this particular theme affects the process of identity construction for the six participants. As 'Adriana' explains:

Mine was not really an urban school but also not too rural in Kuching, Sarawak. It's somewhere in between [laughing]. Anyhow at primary level, I was carefree. Where I was schooled didn't matter to me. But as soon as I got into secondary school, whenever I talked about my school to other teens, they would look at me strangely. Maybe in their heads they label me as a villager or something? I was very active in so many extracurricular activities. So, no matter what the others [other teenagers] think of me or my school, there [her secondary school] I learned how to increase my confidence. Even now at university, if my friend is shy or not able to speak well, I can help that person.

Adriana's experience is perhaps the outlier in the group, as the five other participants shared many negative stories about their time in their rural schools, especially at secondary level. Their self-consciousness about where they went to school was not too pronounced when they were young children, but as they became teenagers and they were more aware of their social identities within their peer group, negative feelings quickly became norm although not to the point of leading them to depression or overpowering their sense of self. Still, the feeling of being in a rural or village school is perhaps not as empowering as being in a large city school. 'Brenda' the only Chinese youngster in the group was particularly affected because she had to go to a 'national school' in Johore compared to children from more well-to-do Chinese families who could send their children to a 'national type school' which is located quite far away from her new village. Brenda recounts her experience:

The neighbourhood [Chinese] kids sometimes don't want to talk to me so much because my Hokkien is bad and my Mandarin is even worse. They made fun of me because I go to a 'sekolah kebangsaan' [national school] where the majority there are of course Malays. I never did think along the lines of me being Chinese or Malay or whatever. My identity is $100 \%$ Malaysian. But being a teenager in this situation, where you go to school matters like hell to these racist people.

\section{Theme \#2 - Teaching Style of Teachers in School}

Again, it was difficult to simply generalise the experiences of the six participants because each of them had their own unique stories to share with us. 'Chitra' the Sindhi participant felt that 
in her own rural school, the teachers were not "particularly good but at the same time they weren't that bad either." She continues:

In our school, like other 'gomen' [government] schools, we used the national KBSR and KBSM syllabus. So, what the teachers taught us is just the same as in the other schools. ... Some teachers helped me to become what I am today by inspiring and motivating me until I've so much confidence especially when I'm having an argument. I think you can call me hard-headed because when you go arguing with people, you don't really have to arrange your words and you just simply push out words [laughing]. I owe these skills to my language teachers. But my other teachers like the history teacher and the science teacher, they just read from the textbooks and expect us to copy down what they dictate. They think we're stupid or what?

Daswann', the only Orang Asli participant and the sole male in the group however faced many bad experiences in his primary school years making him quite passive and scared to talk to other people. It was only when he managed to enter an elite government-funded boarding school at the age of 15 that he was able to break from his cocoon and became the university student that he is today, studying Law under full scholarship from a private foundation due to his excellent grades in his 'Sijil Pelajaran Malaysia' or SPM. At 26 years old, Daswann was also the oldest participant because he had to do Foundation Law for two years. In his mind, the biggest challenge to his sense of self is his Orang Asli identity, in the face of majority ethnic groups that always seemed to look down on this group of native peoples. Indeed, he strongly believes that this was the real reason for the failings of Orang Asli youths in the Malaysian formal education system. He narrates part of his difficult school experience:

I must be the only student studying in a remote primary school. I always feel like that until I feel so alone. ... I can tell you many sob stories about how some teachers would cane my friends for the smallest mistakes. I think these 'outsider' teachers [non-Orang Asli teachers] don't respect us and look down on us. In school, mostly we just repeat what the teachers said non-stop for the whole period. How can we become interested? I'm lucky my father is a Tok Batin [village head]. He pushes me to study and study. But my friends? They just gave up. I'm a fighter, I keep fighting coz I don't want to be left behind. I just become sad every time I remember the bad teachers in my school. I hate them so much, even now.

\section{Theme \#3 - Getting Support from the School}

Whilst some bad schools lead to negative life experiences to the participants, identity is not a one-way street. Bad experiences do not automatically create failures in the lives of individuals, as in the case of Daswann who sees himself as a strong fighter who needs to keep on fighting in his life due to him being an Orang Asli. Indeed, even the smallest gesture of kindness will have positive effects on the personal identity of a person as reported by 'Emma' and 'Firah' with reference to their own school experiences. Emma describes her school experience below:

Some teachers in my school, they take things easy and they just go in and go out of the classroom, just like robots [laughing]. But, not everyone on this earth is bad. Sorry if I sound too philosophical but it's really true-lah. The headmaster of my primary school is for me, the most loving person on earth to me and my friends, apart from my parents of course. So, even if my normal teachers are just so-so, having a good school head teacher made quite a lot of differences in my life even though my school is a small school in a village in Perak. 
Without a tinge of doubt, school support plays a critical role in transmitting knowledge and in shaping a person's identity. In this regard, Malaysian schools should make sure that the person who takes a leadership position is someone who is able to spur positive engagement of students in class. This is also to ensure that students will have positive attitudes in learning and to help them in exposing themselves to the intellectual atmosphere within the classroom. At the same time, a proactive school leader can support students to learn in a proper manner and to motivate them to excel in learning. Supportive schools will drive students to search for new knowledge and to share new ideas with their friends. This will also open up positive identity roles and labels, for example in terms of becoming a confident person, 100\% Malaysian or even a fighter. Firah explains this plainly:

If the head of the school is lazy, you'll have lazy teachers who in turn will produce lazy students. But if you have a good head teacher or principal who can push all the teachers to work hard, then the students will also be pushed to work harder and harder. Of course, the school needs to have all the good facilities and everything else. But my school is just a small secondary school near the Pahang river, and we don't even have great facilities compared to the large city schools. However, we still love going to school because our principal she is very much like a mother to us. I am here today at university because I had a few great teachers like her in my life.

\section{Conclusion}

The findings we obtained suggest that for the participants involved in this empirical research project, their experiences of schooling are considered the dominant space and place to shape their personal and social identities within their lifespan growth and development. Indeed, for these six participants, their experiences of being in bad schools have empowered them to become "a confident person", " $100 \%$ Malaysian" or even "a hard-headed person" and "a fighter", and not merely being labelled as "a villager". That being said, these three themes related to the experiences of schooling in a developing nation's context need to be further explored in more extensive, longitudinal research efforts in the future, perhaps also employing life histories as their primary research methodology (see, for example, Hou, Wang, Bai \& Tang, 2020; Kendellen \& Camiré, 2020; Rainford, 2020). Similar and more elaborate studies on the impacts of the experience of schooling on the process of identity construction could be realistically carried out with participants from other academic programs and courses at other tertiary level institutions in Malaysia and beyond, in order to further elucidate the experience of schooling in a more meaningful and evocative manner.

\section{References}

Abbasi, N. (2016). Adolescent identity formation and the school environment. In K. Fisher (Ed.), The Translational Design of Schools: An Evidence-Based Approach to Aligning Pedagogy and Learning Environments (pp. 81-103). Leiden: Brill Sense.

Adnan, A. H. M. (2006). The link between cognitive development and language acquisition in the early years and implications for language teaching. In K. Ariffin, et al. (Eds.) English in the Malaysian Context (pp. 1-17). Shah Alam: UiTM Press [UPENA].

Adnan, A. H. M. (2012). Perdre sa langue, perdre son identité, se perdre. Le cas des enfants Orang Asli (aborigènes) de Malaise. Droit et Cultures, 63(1), 87-109.

Adnan, A. H. M. (2013a). Language use and identity construction in a 'micro-community' of Malay undergraduates. In R. Machart, C. B. Lim, S. N. Lim, \& E. Yamato (Eds.), Intersecting Identities and Interculturality: Discourse and Practice (pp. 91-110). Newcastle upon Tyne: Cambridge Scholars Publishing. 
Adnan, A. H. M. (2013b). Language use and workplace participation in the identity construction of Bumiputera Malay undergraduates in Malaysia (unpublished Doctor of Philosophy thesis). University of Auckland, New Zealand.

Adnan, A. H. M. (2017a). Being English teachers in Malaysian Islamic schools: Identity narratives from a five year 'Life Journey'. Arab World English Journal, 8(1), 220-233.

Adnan, A. H. M. (2017b). Learning English (and Arabic) in Malaysian Islamic Schools: Language use and the construction of identities. Arab World English Journal, 8(3), 407420.

Adnan, A. H. M. (2018). Industry 4.0 skill sets, higher-order thinking skills and gamification: Lessons from 'Potentia Project', Malaysia (Plenary Panel Presentation). Proceedings from TING X 2018: The Tenth National Meeting of Teachers (Temu Ilmiah Nasional Guru) 'Innovation in Education for Indonesia 4.0'. Tangerang: Universitas Terbuka Indonesia.

Adnan, A. H. M., \& Smith, E. (2001). The social functions of education in a developing country: The case of Malaysian schools and the role of Malaysian teachers. Intercultural Education, 12(3), 325-337.

Agbenyega, J. (2008). Developing the understanding of the influence of School Place on students' identity, pedagogy and learning. International Journal of Whole Schooling, 4(2), 52-66.

Alirezaei, S., \& Roudsari, R. L. (2020). Reflections upon the conduct of phenomenological interviews. Journal of Midwifery and Reproductive Health, 8(1), 1986-1987.

Berezin, M. (2010). Identity through a glass darkly: Review essay of Peter J. Burke and Jan E. Stets, Identity Theory. Social Psychology Quarterly, 73(3), 220-222.

Burke, P. J., \& Stets, J. E. (2009). Identity Theory. New York, NY: Oxford University Press.

Burnard, P., Gill, P., Stewart, K., Treasure, E., \& Chadwick, B. (2008). Analysing and presenting qualitative data. British Dental Journal, 204, 429-432.

Delić, H., \& Bećirović, S. (2016). Socratic method as an approach to teaching. European Researcher, Series A, 10, 511-517.

Demain, S., Goncalves, A. C., Areia, C., Oliveira, R., Marcos, A. J., Marques, A., Parmar, R., \& Hunt, K. (2015). Living with, managing and minimising treatment burden in long term conditions: a systematic review of qualitative research. PloS one, 10(5).

Esteban-Guitart, M., Monreal-Bosch, P., Perera, S., \& Bastiani, J. (2017). Schooling and identity: A qualitative analysis of self-portrait drawings of young indigenous people from Chiapas, Mexico. Frontiers in Psychology, 7(January), 1-12.

Etikan, I., Musa, S. A., \& Alkassim, R. S. (2016). Comparison of convenience sampling and purposive sampling. American Journal of Theoretical and Applied Statistics, 5(1), 1-4.

Flick, U. (2002). Qualitative research - state of the art. Social Science Information, 41(1), 524.

Flick, U., von Kardoff, E., \& Steinke, I. (Eds.) (2004). A companion to qualitative research. London: Sage.

Freire, S., Carvalho, C., Freire, A., Azevedo, M., \& Oliveira, T. (2009). Identity construction through schooling: Listening to students' voices. European Educational Research Journal, 8(1), 80-88.

Gibson, B. J., Drennan, J., Hanna, S., \& Freeman, R. (2000). An exploratory qualitative study examining the social and psychological processes involved in regular dental attendance. Journal of Public Health Dentistry, 60(1), 5-11.

Hou, L., Wang, C., Bai, X., \& Tang, X. (2020). "Life is like this, not as good as poetry": The lived experience of a Chinese rural vocational school student in a mandatory quasiemployment internship. Children and Youth Services Review, 109, 104678. 
Ilias, N., \& Adnan, A. H. M. (2012). Enhancing Learning and Retention Through 'Cognitive Linkages': A Case Study of Malaysian Children. International Journal of the Computer, the Internet and Management, 20(1), 59.1-59.4. Available at SSRN: https://ssrn.com/ abstract=3511704

Kaplan, L., Kuhnt, J., \& Steinert, J. I. (2020). Do no harm? Field research in the Global South: Ethical challenges faced by research staff. World Development, 127, 104810.

Kendellen, K., \& Camiré, M. (2020). Going beyond the interview: Methodological considerations for "getting at" life skills transfer using a longitudinal integrated qualitative approach. Qualitative Research in Sport, Exercise and Health, 12(1), 91107.

Mahajan, A., \& Kaushal, K. (2017). Impact of innovative pedagogical teaching methods on students' academic performance. New Nigerian Journal of Clinical Research, 6(10), 41-44.

Major, C. H., \& Savin-Baden, M. (2010). An introduction to qualitative research synthesis: Managing the information explosion in social science research. London: Routledge.

Marwan, A., Sumintono, B., \& Mislan, N. (2012). Revitalizing rural schools: A challenge for Malaysia. In Educational Issues, Research and Policies (pp. 172-188). Skudai, RMCUTM Press.

Raburu, P. A. (2015). The self - Who am I? Children's identity and development through Early Childhood Education. Journal of Educational and Social Research, 5(1), 83-85.

Rahmat, A. M., Adnan, A. H. M., \& Mohtar, N. M. (2019). Industry 4.0 skillsets and 'Career Readiness': Can Malaysian university students face the Future of Work? In MNNF Network (Ed.), Proceedings of the International Invention, Innovative \& Creative (InIIC) Conference, Series 2/2019 (pp. 28-37). Senawang: MNNF Network.

Rainford, J. (2020). Confidence and the effectiveness of creative methods in qualitative interviews with adults. International Journal of Social Research Methodology, 23(1), 109-122.

Shah, D. S. M., Adnan, A. H. M., Mohd Salim, M. S. A., Yusof, A. M., \& Tahir, M. H. M. (2020). The non-formal education of Orang Asli adolescents in Malaysia: From community to university. Paper presented at the International Conference on Teacher Education (ICTE'20), 18-19 ${ }^{\text {th }}$ March, Grand Riverview Hotel, Kelantan, Malaysia.

Shah, D. S. M., Adnan, A. H. M., Perumal, D., Yusof, J., Veeravagu, J., \& Kamarudin, S. (2020). The influence of schooling on the identities of undergraduate students in Malaysia. Paper presented at the 4th International Conference on Education, Business, Islamic and Technology (ICEBIT 2020), 11-12 ${ }^{\text {th }}$ January, Hotel Casuarina @ Meru, Perak, Malaysia.

Showkat, N., \& Parveen, H. (2017). Non-probability and probability sampling [Online]. Available at https://www.researchgate.net/publication/319066480_NonProbability_and_Probability Sampling. Accessed, February $14^{\text {th }}, 2020$.

Sirin, S. R. (2005). Socioeconomic status and academic achievement: A meta-analytic review of research. Review of Educational Research, 75(3), 417-453.

Smith, E. P., Walker, K., Fields, L., Brookins, C. C., \& Seay, R. C. (1999). Ethnic identity and its relationship to self-esteem, perceived efficacy and prosocial attitudes in early adolescence. Journal of Adolescence, 22, 867-880.

Soto, C. J., \& Tackett, J. L. (2016). Personality traits in childhood and adolescence: Structure, development, and outcomes. Cancer Research, 76(4), 358-362.

Stets, J. E., \& Burke, P. J. (2014a). Self-esteem and identities. Sociological Perspectives, 57(4), 409-433.

Stets, J. E., \& Burke, P. J. (2014b). The development of identity theory. Advances in Group Processes, 31(1), 57-97. 
Stuckey, H. L. (2014). The first step in data analysis: Transcribing and managing qualitative research data. Journal of Social Health and Diabetes, 2(01), 006-008.

Sylva, K. (1994). School influences on children's development. Journal of Child Psychology and Psychiatry, 35(1), 135-170.

World Economic Forum (2016a). Human Capital Outlook Association of Southeast Asian Nations (ASEAN). Geneva: World Economic Forum.

World Economic Forum (2016b). The Future of Jobs: Employment, Skills and Workforce Strategy for the Fourth Industrial Revolution. Geneva: World Economic Forum.

World Economic Forum (2018). The Future of Jobs Report 2018. Geneva: World Economic Forum.

Zepatou, V., Loizidou, M., Chaloulakou, A., \& Spyrellis, N. (2016). School facilities and sustainability-related concepts: A study of Hellenic secondary school principals', teachers', pupils' and parents' responses. Sustainability (Switzerland), 8(4), 1-28. 